NBER WORKING PAPER SERIES

\title{
MEDIA COVERAGE OF POLITICAL SCANDALS
}

\author{
Riccardo Puglisi \\ James M. Snyder, Jr. \\ Working Paper 14598 \\ http://www.nber.org/papers/w14598

\section{NATIONAL BUREAU OF ECONOMIC RESEARCH 1050 Massachusetts Avenue Cambridge, MA 02138} \\ December 2008
}

We thank John Lovett and Mike Naber for their valuable research assistance at different stages of the project. We also thank Gabe Lenz, Maria Petrova and Glenn Richardson for their helpful comments. The views expressed herein are those of the author(s) and do not necessarily reflect the views of the National Bureau of Economic Research.

NBER working papers are circulated for discussion and comment purposes. They have not been peerreviewed or been subject to the review by the NBER Board of Directors that accompanies official NBER publications.

(C) 2008 by Riccardo Puglisi and James M. Snyder, Jr.. All rights reserved. Short sections of text, not to exceed two paragraphs, may be quoted without explicit permission provided that full credit, including (C) notice, is given to the source. 
Media Coverage of Political Scandals

Riccardo Puglisi and James M. Snyder, Jr.

NBER Working Paper No. 14598

December 2008

JEL No. D72,L82

\title{
$\underline{\text { ABSTRACT }}$
}

We analyze the coverage of U.S. political scandals by U.S. newspapers during the past decade. Using automatic keyword-based searches we collected data on 35 scandals and approximately 200 newspapers. We nnd that Democratic-leaning newspapers -- i.e., those with a higher propensity to endorse Democratic candidates in elections -- give relatively more coverage to scandals involving Republican politicians than scandals involving Democratic politicians, while Republican-leaning newspapers tend to do the opposite. This is true even when controlling for the average partisan leanings of readers. In contrast, newspapers appear to cater to the partisan tastes of readers only for local scandals.

\author{
Riccardo Puglisi \\ ECARES \\ Université Libre de Bruxelles \\ Avenue Adolphe Buyl 87 \\ 1050 Ixelles, Belgium \\ rpuglisi@mit.edu \\ James M. Snyder, Jr. \\ MIT Department of Economics \\ E53-457 \\ 50 Memorial Drive \\ Cambridge, MA 02142-1347 \\ and NBER \\ millett@mit.edu
}




\section{Introduction}

In modern societies the mass media are citizens' most important source of information about public affairs. On some issues, such as crime or the state of the economy, citizens can compare the news provided by the media with their personal experience. On other issues, such as foreign affairs, the media are the only source of information available to most of the public.

Events concerning the malfeasance of public officials typically fall into the second category. Politicians may wish to communicate directly with voters about certain matters, such as popular policy decisions, but they clearly have no incentive to advertise their wrongdoings. As a result, the mass media have the potential to play a crucial role as watchdogs, informing citizens about any improper conduct by those in power.

Of course, in practice the media might or might not serve as faithful watchdogs. In particular, according to the "agenda-setting" theory of mass media, editors and journalists enjoy considerable freedom in deciding what is newsworthy and what is not, and these choices affect the perception of citizens about which issues are relevant and to what extent. As pointed out by Lippmann [1922], events regarding public affairs would be "out of reach, out of sight, out of mind" for citizens if the media happen not to cover them.

In this paper we investigate the coverage of political scandals by approximatively 200 U.S. newspapers during the last decade. We collect data on media coverage through automated keyword-based searches of the NewsLibrary electronic archive, and focus on scandals involving senators, members of congress, and state governors. Exploiting the newspapers' own archives and the Factiva electronic archive we integrate our dataset with similar information on the New York Times, the Los Angeles Times and the Chicago Tribune. We use this data to test several hypothesis regarding the political behavior of mass media. We match this data with a measure of the explicit partisan position of each newspaper, and a measure of the partisanship of each newspaper's readers. The former is the average propensity to endorse Democratic versus Republican candidates in congressional and statewide races, and 
the latter is the propensity to vote for Democratic versus Republican candidates in the areas in which each newspaper is sold, weighted by circulation. We also use the circulation data to construct measures of the competitiveness of each newspaper market.

The main finding of our analysis is that the ideological position on the "supply side" is strongly correlated with the partisan coverage of scandals, and with the expected sign. Democratic-leaning newspapers - i.e., those with a higher propensity to endorse Democratic candidates in elections - give significantly more coverage to scandals involving Republican politicians than scandals involving Democratic politicians, while Republican-leaning newspapers do the opposite. This bias in coverage of scandals is not confined to the editorial page, but also affects the news section. ${ }^{1}$

On the other hand, we find that "demand side" factors play a significant role only for local scandals. Newspapers mainly read in Democratic (Republican) areas give significantly more coverage to Republican (Democratic) scandals, but only when the politicians involved in the scandal are from the same state or congressional district where the newspaper is sold. This difference in coverage does not hold for "distant" scandals. In contrast, the supply side effect described in the previous paragraph - that Republican-endorsing newspapers systematically give more coverage to Democratic scandals, and Democratic-endorsing newspapers do the opposite - holds irrespective of the geographical location of the politicians involved.

The relative frequency of stories about political scandals is on average quite small. Thus, in absolute terms the effects we measure are also small. In relative terms, however, the biases are large. Consider a newspaper with a propensity to endorse Democratic candidates that is one standard deviation higher than average. On average, this newspaper would devote 26 percent more coverage to Republican scandals over Democratic scandals. To have a rough idea of the relative positions, a standard deviation in the endorsement score is what separates

\footnotetext{
${ }^{1}$ Although the relationship between endorsement behavior and readers' partisanship is positive and statistically significant, the correlation is rather low, only about .28. Thus, there is evidently a lot of "slack" between the partisan positions of readers and the editorial stances of newspapers. This suggests that the endorsement behavior of a given newspaper is a reasonable indicator of "supply side" forces pinning down its editorial position. We discuss this in more detail in section 3 below.
} 
the Chicago Tribune from the Denver Post, and in turn the Denver Post from the New York Times.

Finally, there is some evidence that newspapers with larger circulation systematically give more space to scandals, irrespective of the political affiliation of those involved. As discussed below, there are both demand-driven and supply-led accounts consistent with this relationship.

The paper is organised as follows: in the next section we survey the theoretical and empirical literature on the determinants and measurement of mass media bias. In section 3 we describe the data and in section 4 we give a preliminary look at them through a two-stage analysis. Section 5 presents the results obtained from a one-stage procedure with interaction terms, together with some robustness checks, while section 6 concludes.

\section{Related Literature}

\subsection{Theory}

What determines the amount of media coverage devoted to political scandals? On the supply side, stakeholders such as owners, editors and journalists might pursue partisan agendas. In this case, Democratic-leaning newspapers would extensively cover scandals involving Republican politicians, and devote less coverage to those involving Democratic politicians. Republican-leaning newspapers would do the opposite. Gentzkow et al. [2006] develop a simple model of ideological newspapers. A newspaper can pay a cost to investigate and acquire a newsworthy "story", but it will not publish the story if it conflicts with the newspaper's political leaning. The incentives to pay the costs of investigation depend on the incentives to suppress unfavorable stories, which depend in turn on how much advertising and circulation revenue would be lost by not publishing them.

The role played by the demand side depends on whether readers consume news in order to acquire information or to confirm their prior beliefs. Confirmation-seeking readers might enjoy reading about scandals involving politicians on the opposite side of the political spec- 
trum, and dislike reading about scandals involving politicians from their preferred side. In this case, to the extent there is a partisan or ideological match between the consumers and suppliers of news, the supply side and demand side forces both push news coverage in the same direction. ${ }^{2}$

Media outlets may have an incentive to slant coverage even if consumers are purely information-seeking. Gentzkow and Shapiro [2006] show that media outlets will tend to report news in a manner consistent with their readers' prior beliefs in order to build and maintain a reputation for high-quality journalism. ${ }^{3}$

On the other hand, if the demand for information drives news consumption and the decisions made by consumers are discrete choices (e.g., casting a vote for one of two parties), then only individuals that can be induced to change their course of action should be interested in acquiring the information. Ideologically moderate and independent citizens should therefore have stronger incentives to obtain information than ideological extremists and loyal partisans. While each new piece of news is potentially useful to moderates, almost no amount of news could change an extremist's behavior. ${ }^{4}$ This suggests that newspapers that appeal to moderates or independents should tend to cover all political scandals, irrespective of the political affiliation of the politicians involved.

Another issue is newspaper size. It is unclear a priori whether newspapers circulating in a large city should devote more overall coverage to political scandals than newspapers in smaller cities. Suppose that (i) readers are confirmation seekers who like to read about scandals involving politicians from the opposition party, and (ii) larger audiences tend to be more ideologically heterogeneous or more diverse in terms of partisanship. Then, as long as

\footnotetext{
${ }^{2}$ Mullainathan and Shleifer [2005] build a game-theoretical model of news consumption in which readers are willing to pay for ideologically consonant coverage. In our context, readers would be willing to pay for the omission of facts that conflict with their priors.

${ }^{3}$ In the Gentzkow and Shapiro [2006] model newspapers sometimes make mistakes, and some newspapers are more likely to make mistakes than others. Readers have prior beliefs about what is more likely to be true and what is not, and are also uncertain about the quality of their newspaper. They then update their beliefs in a Bayesian fashion based on what they read. The results are similar in spirit to those on "pandering" in Canes-Wrone et al. [2001].

${ }^{4}$ See Larcinese [2006] for a model yielding this type of prediction.
} 
readers can simply skip over the articles covering scandals involving politicians from their preferred ideology or party (or do not dislike reading these articles too much), a newspaper catering to the larger audience is likely to find it profitable to cover scandals involving both parties' politicians, and hence will devote more coverage overall to scandals. That is, a newspaper that initially covered only Republican scandals would increase its profits if it decided to cover Democratic scandals as well, because it would gain more readers among Republicans than it would lose among Democrats. There is also an obvious supply side factor - newspapers with larger circulation also have more resources, and might choose to assign more staff to investigative reporting and coverage of scandals.

A final issue is competition. There are several reasons why the amount of competition faced by media outlets could affect the level and bias in the coverage of scandals. If media bias is driven mainly by the ideological leaning of journalists and editors, then a more competitive media market is likely to mitigate the degree of bias. A partisan newspaper enjoying a local monopoly can unabashedly disregard those scandals involving politicians from its preferred party. On the other hand, in the presence of competitors, each newspaper might be induced to devote some attention to scandals on both sides, in order not to lose readers, and revenue, to other newspapers that do. Competition might also interact with demand-side factors. The Mullainathan and Shleifer [2005] model predicts that competition may increase the amount of "bias" (ideological differentiation) in media coverage. ${ }^{5}$ On the other hand, the Gentzkow and Shapiro [2006] model predicts the opposite. ${ }^{6}$

\footnotetext{
${ }^{5}$ In their model a monopolistic newspaper will position itself in the middle of the ideological spectrum of its market area, while in a duopoly situation the newspapers would locate on opposite sides of the middle, each carving out a part of the readership for itself.

${ }^{6}$ In their model, increased competition tends to reduce the bias (increase the accuracy) of each newspaper. The reason is that with a larger number of media outlets readers will typically have access to follow-up stories that investigate the accuracy of prior stories ("scoops"). So newspapers ex ante face stronger incentives to report in an unbiased fashion.
} 


\subsection{Previous empirical studies}

There is a growing empirical literature which attempts at finding replicable and intuitive measures of the ideological position of media outlets.

One straightforward way to do this is to investigate the explicit political behavior of media outlets, e.g. their endorsements in races for political offices. ${ }^{7}$ Ansolabehere et al. [2006] analyze the political orientation of endorsements by U.S. newspapers in statewide and congressional races, using a panel data design. They find an upward trend in the average propensity to endorse one or the other major-party candidate. They also find a particularly large increase in the propensity to endorse incumbents. Finally, they find a clear change in the average partisan slant of endorsements. In the 1940s and 1950s Republican candidates enjoyed a strong advantage in newspaper endorsements. This advantage gradually eroded in subsequent decades, so that by the 1990s there was a slight tendency for newspapers to endorse Democrats (even controlling for incumbency).

One might instead be concerned about the implicit political behavior of media outlets. Potentially, this is a more insidious way for media outlets to act politically, since readers and viewers might not be entirely aware of the bias to which they are being exposed.

There are two broad approaches used to estimate this implicit ideological stance. In the first approach, mass media outlets are classified on the basis of the resemblance between what they report and what political actors of a known ideological position do.

Groseclose and Milyo [2005] classify U.S. media outlets by tracing out which think tanks are quoted by each of them. The political leaning of each think tank is recovered by looking at the political position (ADA score) of members of the U.S. Congress who quote the same think-tank in a non-negative way. In a nutshell, the political leaning of each outlet can then be calculated as the average ideology of quoted think-tanks. They find that all the outlets in their sample - except Fox News Special Report and the Washington Times - are located

\footnotetext{
${ }^{7}$ This is of course feasible only in a context where media outlets routinely endorse candidates in electoral races.
} 
to the left of the average Congress member. At the same time, all outlets but one (the Wall Street Journal) are located between the average Democrat and the average Republican Congressmen, hence displaying a high degree of centrism. ${ }^{8}$

Gentzkow and Shapiro [2007] provide another measure of media bias based on similarities between the language used by media outlets and congressmen. Exploiting the Congressional Record, they identify "partisan" words and phrases - i.e., those expressions that show the largest difference in the frequency of use between Democratic and Republican representatives. They then measure how frequently these expressions appear in a very large sample of newspapers. They conclude that the partisan bias of newspapers depends mainly on consumers' ideological leaning and far less on the identity of owners. Newspapers adopting a liberal (conservative) language sell more copies in ZIP codes that are more liberal (conservative), as proxied by the propensity of their inhabitants to donate to Republican or Democratic candidates. On the other hand, once geographical factors are accounted for, the ideological slant of a given newspaper is not significantly correlated with the average ideological slant of those belonging to the same chain.

The second approach to measuring the implicit political positions of media outlets is based on studying variation in the intensity with which they cover different topics, or by studying variation in the tone of this coverage.

Puglisi [2006] provides an account of the agenda setting behavior of the New York Times in the period 1946-1997. He finds that the Times displays pro-Democratic partisanship, with some watchdog aspects, in that, during presidential campaigns, it systematically gives more coverage to Democratic topics (civil rights, health care, labor and social welfare) when the incumbent president is a Republican. ${ }^{9}$ The New York Times displays a more symmetric type

\footnotetext{
${ }^{8}$ Gasper [2007] explores the robustness of the Groseclose and Milyo findings. He argues that their conclusions are robust to different measures of the ideological positions of senators and congressmen, but not to the time window being considered. In particular, the average estimated ideological position of the media shifts to the right if one uses more recent time windows.

${ }^{9}$ In accord with the theory of issue ownership, as pioneered by Petrocik [1996], an issue is said to be "Democratic" (or owned by the Democratic party) if the majority of citizens stably believes that Democratic politicians would be better than Republican ones at handling problems related to it.
} 
of watchdog behavior after 1960: over the last four decades, during presidential campaigns the Times also gives more coverage to the typically Republican issue of Defense when the incumbent president is a Democrat, and less so when the incumbent is a Republican.

Larcinese et al. [2007] analyse the coverage of economic issues by a large sample of U.S. newspapers during the last decade. They study whether there is any significant correlation between the endorsement policy of newspapers, and the differential coverage of bad/good economic news as a function of the political affiliation of the incumbent president. They find evidence that newspapers with pro-Democratic endorsement pattern systematically give more coverage to high unemployment when the incumbent president is a Republican than when the president is Democratic, compared to newspapers with pro-Republican endorsement pattern. Once controlling for the endorsement behavior of newspapers, the partisan coverage of unemployment is not driven by the partisanship of readers. On the other hand, there is no evidence of a partisan bias that is correlated with the endorsement policy for stories on inflation, budget deficit or trade deficit.

The papers by Puglisi [2006] and Larcinese et al. [2007] investigate the agenda-setting behavior of media outlets, i.e. the amount of coverage devoted to different issues. ${ }^{10}$ Other papers examine bias in the "tone" of coverage. For example, Lott and Hassett [2004] analyze newspaper coverage when official data about various economic indicators are released. They code the tone - positive or negative - of newspaper headlines, and relate this to the partisanship of the sitting president. Controlling for the economic data being released, they find that there are between 9.6 and 14.7 percent fewer positive stories when the incumbent president is a Republican.

\footnotetext{
${ }^{10}$ The theory of agenda-setting effects, as pioneered by the study by McCombs and Shaw [1972] on Chapel Hill voters during the 1968 presidential campaign, posits that the amount of coverage devoted to an issue by the media can influence the importance readers and viewers attach to that issue. See Iyengar et al. [1982] for some experimental evidence on this. As noted by McCombs [2002], not only can mass media coverage highlight some topic as an object of attention, but the coverage can also emphasize particular attributes of the topic, making these attributes more salient. The theory of issue priming describes how readers and viewers, when assessing a given situation or individual, are pushed towards giving a higher weight to the aspect emphasized by the mass media. See Krosnick and Miller [1996] for a review of this literature.
} 
Finally, a few studies attempt to determine whether media bias affects political attitudes and decisions. In addition to the literature in communications studies on agenda-setting and framing effects, there are some recent papers examining the effects of variation in the diffusion of given media outlets, whose political position is assumed to be known. Gerber, Karlan and Bergan [2006] conducted a randomized field experiment just before the November 2005 gubernatorial election in Virginia. In the experiment, some households received a free subscription to the Washington Post, others received a free subscription to the Washington Times, and others received no free newpaper. DellaVigna and Kaplan [2007] use instead a quasi-experimental approach, and exploit the gradual introduction of Fox News in cable markets, in order to estimate its impact on the vote share in presidential elections between 1996 and 2000.

With respect to research on media coverage of political scandals, the Watergate affair looms large. Watergate stimulated considerable interest in how scandals are covered - and sometimes even uncovered - by the mass media. The causes and consequences of Watergate have been widely investigated (e.g., Bernstein [1976], Chomsky [1973], Lang and Lang [1980], Lipset and Raab [1973], Schrag [1974] and Zimmer [1979]), and in some cases Watergate is used as a benchmark against which other scandals are to be compared (Szasz [1986]). One issue debated in the political science and communications literatures is whether the mass media act as efficient watchdogs in their coverage of political scandals, or whether they instead inject an excessive dose of sensationalism, making the public skeptical and ultimately cynical and unresponsive (Francke [1995], Balkin [1999], Bennett and Serrin [2005]).

A related issue, which is the explicit focus of our empirical analysis, is whether the coverage of scandals is partisan or balanced. Regarding this question, the closest contribution to ours is the historical analysis by Gentzkow et al. [2006] on how U.S. newspapers covered the Crédit Mobilier scandal in the early 1870s and the Teapot Dome scandal in the 1920s. The authors note that in the period between these scandals technological progress in the printing industry, coupled with the contemporaneous increase in the population and income 
of U.S. cities, induced an enormous growth in the size of the newspapers' market, with subscriptions climbing from 2.6 millions in 1870 to 33 millions in 1920. In the competition for market shares and advertising revenue, newspapers faced strong incentives to cut the ties with political parties and become (at least formally) independent. ${ }^{11}$ The authors find that the coverage of the Crédit Mobilier scandal - which occured in a period dominated by partisan newspapers - was more biased than the coverage of Teapot Dome - which occured at a time when fewer dailies were directly linked to political parties. They also find some evidence that the coverage of the Crédit Mobilier scandal was less biased for newspapers with higher circulation. ${ }^{12}$

Our contribution to this literature is to analyse the coverage devoted to a large number of recent political scandals by a large set of newspapers. By using automatic keyword-based searches, we are thus able to offer a replicable and more precise estimation of the agendasetting bias on an extremely contentious, salient, and important topic. In addition, we match the data on coverage with measures of endorsement and reader partisanship, allowing us to investigate the comparative impact of demand and supply factors in explaining slanted coverage.

Our paper also makes a methodological contribution. Antweiler and Frank [2005] argue that automated text-classification procedures allow researchers to investigate a comprehensive dataset of news items, possibly the entire population of interest. Because of its cost, studies employing human-based content analysis must instead focus on a small subset of the relevant population - in our case, this would likely mean limiting attention to a few scandals by a small number of media outlets. This may increase the risk of various biases, including publication bias - i.e., the tendency to over-publish significant and seemingly interesting results. As Antweiler and Frank point out, researchers and scientific journal editors enjoy considerable freedom to engage in cherry-picking, because the universe of studies employ-

\footnotetext{
${ }^{11}$ See Petrova [2007] for an explicit empirical analysis of the link between potential advertising revenue across U.S. cities and entry/exit of partisan and independent newspapers during the $19^{\text {th }}$ century.

${ }^{12}$ The relationship was not statistically significant except when they excluded the New York Herald.
} 
ing human-based content analysis is so large. The comprehensive data treatment allowed by automated procedures reduces this type of bias, by sharply restricting the "degrees of freedom" available to the researcher. In our case, for example, we simply choose to focus on recent and salient political scandals in the U.S. involving a particular class of politicians (members of congress and top statewide officials). Once we have made this choice, we measure the coverage of all scandals satisfying the selected criteria on all newspapers that are available in the NewsLibrary archive (plus the New York Times, the Chicago Tribune and Los Angeles Times, which we add because they are the largest newspapers in the U.S. that endorse candidates but are not searchable through NewsLibrary).

\section{Data and Measures}

In the analysis that follows we focus on recent political scandals involving U.S. senators, congressmen, governors and high-ranking members of the administration (plus one especially prominent lobbyist, Jack Abramoff). Table 1 presents an overview of those scandals, giving the position, state of origin, political affiliation of the persons involved, and a brief description of each scandal. Our sample comprises 14 scandals involving Democratic politicians, and 21 involving Republicans. All scandals in the sample involved a prominent federal or state investigation, and many resulted in indictments and felony convictions. On the Democratic scandals we see Robert Torricelli (Sen-NJ) and William Jefferson (Rep-LA) accused of accepting bribes, and Don Siegelman (Gov-AL) convicted of racketeering and extortion. On the Republican side, we see Bill Frist (Sen-TN, Majority Leader) accused of insider trading, Tom DeLay (Rep-TX, Majority Leader) charged with accepting illegal corporate donations and money laundering, and Randy "Duke" Cunningham (Rep-CA) convicted of soliciting and accepting bribes.

For each of these 35 scandals, we collected data from the NewsLibrary electronic archive, recording the total number of articles mentioning the person involved in each available news- 
paper during a fixed time window. ${ }^{13}$ The time window for each scandal begins on the first day of the month prior to an announced investigation by a federal agency, a congressional ethics committee, or a state attorney general, and ends at the end of the month in which the person involved was convicted or acquitted (if this occured), or at the end of the month in which the investigation formally ended (if this occurred), or at the end of the month when the member lost reelection or resigned (if this occured), or on June 30, 2007 if the investigation was still ongoing at that date. ${ }^{14}$ The politicians in our sample have prominent public roles which make them newsworthy for a variety of reasons. In order to restrict attention to articles covering the scandals themselves, we code an article as being about the scandal if the name of the person involved appears together with the one or more of the following words (*'s are wildcards): investigat*, indict*, convict*, guilty, resign*, brib*, ethic*, corrupt*, conspir*, prison, scandal*. To find opinion articles we added the following qualifiers to the "Topic" and "Section" fields in the search: opinion, editorial, comment, commentary, perspective, viewpoint, forum, ideas, citizen voices, sunday punch. ${ }^{15}$ We define "news" articles all non-opinion articles. ${ }^{16}$

Since newspapers vary greatly in size cross-sectionally (total number of pages, stories, and words), and can also vary in size over time, we focus on the relative frequency of articles about a scandal in each newspaper during the relevant time window. In order to do so, we proxy the total number of articles in each newspaper in each time period by running a search on the word "and". We do the same for opinion pieces, by adding the qualifiers listed above to the "Topic" and "Section" fields when searching for the word "and".

The first half of Table 2 displays summary statistics on scandal coverage for those newspapers that we were able to match with endorsement data. We express relative frequencies

\footnotetext{
${ }^{13}$ As mentioned above, we use the newspapers' own archives to add data on the Los Angeles Times and the Chicago Tribune, and the Factiva archive for the New York Times.

${ }^{14}$ Most federal investigations are by the FBI, but the SEC and IRS are also involved in some cases.

${ }^{15}$ This failed to find the editorial page for a few newspapers, so we dropped these from the analysis.

${ }^{16}$ Regarding the New York Times, the Los Angeles Times and the Chicago Tribune, the online archives allow to explicitly restrict the searches to the editorial page: we directly follow this simpler route to retrieve opinion pieces.
} 
of stories in percentage points, and distinguish between total hits, articles and editorials. Overall, scandal stories make up a very small fraction of the total: on average there are around two and a half hits every 10,000 stories. This figure is much higher for editorials (something more than one editorial every 1,000). For all three categories of hits, the distribution is strongly skewed to the right, as witnessed by large difference between mean and median.

In order to control for the relative localness of a scandal, we construct the dummy variable Instate, which equals one when the politician involved in scandal $i$ is from the state where newspaper $j$ is located. In a similar fashion Local is a dummy which equals one when the politician involved in scandal $i$ is from a congressional district that overlaps heavily with the market area of newspaper $j$ (for congressional scandals). Summary statistics on these variables are again reported in the first half of Table 2.

As mentioned, we match data on the coverage of scandals with information on the endorsement propensity of each newspaper. The main source of endorsement data is Ansolabehere et al. [2006], which we supplement with additional information obtained via searches on the NewsLibrary archive. ${ }^{17}$

We define the "partisan bias" of a newspaper as the propensity for the newspaper to endorse one of the parties during electoral campaigns, controlling for the quality of candidates and their incumbency status. We used a linear regression model to estimate these biases. Let $i$ index offices, let $j$ index newspapers and let $t$ index years. Let

$$
E_{i j t}=\left\{\begin{aligned}
1 & \text { if newspaper } j \text { endorses Democrat for office } i \text { in year } t \\
-1 & \text { if newspaper } j \text { endorses Republican for office } i \text { in year } t \\
0 & \text { if newspaper } j \text { explicitly makes no endorsement for office } i \text { in year } t
\end{aligned}\right.
$$

measure the endorsement behavior by each newspaper endorsing a candidate in a race (ex-

\footnotetext{
${ }^{17} \mathrm{~A}$ few newspapers have an explicit policy not to endorse candidates for political offices - e.g. the Deseret News in Salt Lake City, the Orange County Register, and the Colorado Springs Gazette. In addition, many smaller dailies do not bother to make political endorsements.
} 
plicitly refusing to do so). ${ }^{18}$ Also, let

$$
I_{i j t}=\left\{\begin{aligned}
1 & \text { if Democrat for office } i \text { in year } t \text { is only incumbent } \\
-1 & \text { if Republican for office } i \text { in year } t \text { is only incumbent } \\
0 & \text { if otherwise }
\end{aligned}\right.
$$

measure the incumbency status of the candidates in each race. ${ }^{19}$ Finally, we use previous electoral experience to measure the quality of non-incumbents. To be more specific, define a "high-quality" candidate as a candidate who currently holds a U.S. House seat or an elected statewide office other than the office sought. Let

$$
Q_{i j t}=\left\{\begin{aligned}
1 & \text { if Democrat for office } i \text { in year } t \text { is only high quality non-incumbent } \\
-1 & \text { if Republican for office } i \text { in year } t \text { is only high quality non-incumbent } \\
0 & \text { otherwise }
\end{aligned}\right.
$$

We estimated the following linear model for the period 1992-2006, exploiting the panel nature of the data:

$$
E_{i j t}=N E_{j}+\theta_{t}+\beta_{1} I_{i j t}+\beta_{2} Q_{i j t}+\epsilon_{i j t}
$$

The newspaper-specific fixed effects, $N E_{j}$, capture newspapers' partisanship. $^{20}$

Overall, we have sufficient data on both endorsements and scandal coverage for 213 newspapers. $^{21}$

We measure of the average partisanship of each newspapers' readers as follows. First, for each county $c$ we compute $D_{c}$ as the average Democratic vote share in the presidential, senatorial and gubernatorial elections between 1990 and 2000. Then, for each newspaper $j$ we compute $N R_{j}$ as a weighted average of the $D_{c}$ 's, weighting each county by the relative sales of newspaper $j$ in that county. We call this variable $N R_{j}$. Figure 1 displays a scatter

\footnotetext{
${ }^{18}$ Our sample contains a few cases where a newspaper endorsed both candidates in a race. We drop these from our analysis.

${ }^{19}$ After redistricting there are some U.S. House races with two incumbents running. In these cases we set $I_{i j t}=0$. There are a few such cases in our sample, and if we drop them the results are unchanged.

${ }^{20}$ The panel is unbalanced, since in the earlier years some newspapers lack endorsement data. The model also includes year fixed-effects, $\theta_{t}$, which are meant to capture partisan tides.

${ }^{21}$ When matching coverage and endorsement data, newspapers under a joint operating agreement are tricky cases. These agreements typically imply that the news section is common among participants, while the editorial sections are separate. However, in four such instances the NewsLibrary archive reports data for only one outlet. We dropped those cases (i.e. eight outlets).
} 
plot of the endorsement partisanship $N E_{j}$ against readers' ideology $N R_{j}$, together with the estimated regression line. As one might expect, there is a statistically significant correlation between the ideological stance of the demand and the supply side. But the correlation is only .28, which is not overwhelming. Evidently, there is a lot of "slack" between the partisan positions of news consumers and news providers.

We measure the relative percentage of moderates (or partisan independents) among each newspapers' readers in a similar fashion. First, for each county $c$ we compute $s d_{c}$ as the standard deviation of the Democratic vote share in the presidential, senatorial and gubernatorial elections between 1990 and $2000{ }^{22}$ Then, for each newspaper $j$ we compute $N R_{-} s d_{j}$ as a weighted average of the $s d_{c}$ 's, again weighting each county by $j$ 's relative sales in the county.

We measure newspaper size as the average annual circulation during the period 19962002.

Finally, to measure the competitive pressure facing each newspaper in its relevant markets, we again use data from 1996 to 2002 and proceed as follows. Let $s_{j c t}$ be the share of copies sold by newspaper $j$ in county $c$ during year $t$. Our index is based on the probability of a random meeting between an individual living in county $j$ who reads newspaper $j$ with another individual living in the county who reads a different newspaper. This probability is $s_{j c t} \times\left(1-s_{j c t}\right)$. We average this across years and weight it by the relative sales of each newspaper in each county. Call this measure Compet $_{j}$.

Summary statistics for all independent variables are reported in Table 2.

\footnotetext{
${ }^{22}$ The standard deviation is widely used as a proxy for the relative share of independents or moderates in states, districts, and counties. This measure was introduced by Wright [1974]. See also Wallis [1984]. An area where the vote exhibits large fluctuations between the two parties presumably has a large share of independents or moderates, since loyal partisans and ideological extremists will rarely change their vote between elections.
} 


\section{Two-Stage Analysis}

We begin with a simple and intuitive two-stage analysis. First we separately estimate newspaper-specific propensities to cover Democratic and Republican scandals, controlling for factors such as whether the scandal involves a politician from the same state or city as the newspaper. Then we regress the difference in these estimated propensities against our measures of endorsement partisanship and reader partisanship.

More precisely, for each Democratic scandal $i=1, \ldots, 14$, let $n_{i j}^{D}$ be the relative frequency of articles published by newspaper $j$ about scandal $i$ during the relevant time window. Define $n_{i j}^{R}$ similarly, for each Republican scandal $i=1, \ldots, 21$. We run the following two panel regressions:

$$
\begin{aligned}
& n_{i j}^{D}=\alpha_{i}^{D}+\beta_{j}^{D}+\delta_{1}^{D} \text { Instate }_{i j}+\delta_{2}^{D} \text { Local }_{i j}+\epsilon_{i j}^{D} \\
& n_{i j}^{R}=\alpha_{i}^{R}+\beta_{j}^{R}+\delta_{1}^{R} \text { Instate }_{i j}+\delta_{2}^{R} \text { Local }_{i j}+\epsilon_{i j}^{R}
\end{aligned}
$$

where $\alpha_{i}^{D}$ and $\alpha_{i}^{R}$ are scandal-specific fixed effects; $\beta_{j}^{D}$ and $\beta_{j}^{R}$ are newspaper-specific fixed effects; the Instate and the Local dummy variables are described above. Since we have data not only on the overall coverage of scandals on the newspaper, but separate information on the coverage devoted on the editorial page and on the news section, we can perform these regressions on three different items: relative frequencies of total hits, relative frequencies of news hits, and relative frequencies of opinion hits.

Our focus is on the differential coverage of Republican and Democratic scandals by the different newspapers, which we can compute from the newspaper-specific fixed effects. Let $\hat{s}_{j} \equiv \hat{\beta}_{j}^{R}-\hat{\beta}_{j}^{D}$ measure the degree to which newspaper $j$ exhibits a relatively pro-Democratic bias in its scandal coverage. ${ }^{23}$

Once we obtain these newspaper-specific measures of slanted coverage, we check whether and how they correlate with the explicit partisan position of each newspaper, as proxied by

\footnotetext{
${ }^{23}$ Note that this is only a relative measure - we do not make any claims about the absolute ideological position of media outlets.
} 
its endorsement pattern, and with the political leaning of consumers. The results of this exercise (with heteroskedasticity-robust standard errors) are shown in Table 3. We present results for three dependent variables: total hits, news hits and editorial hits. For each dependent variable we present the results of four regressions: in the first we simply regress $\hat{s}_{j}$ against the endorsement partisanship $N E_{j}$ and a constant, in the second we do the same with reader partisanship $N R_{j}$, in the third we control for both $N E_{j}$ and $N R_{j}$, and in the fourth we add total average circulation as an additional control, expressed in thousands of yearly copies.

The main finding is that pro-Democratic coverage of scandals is significantly and positively correlated with a pro-Democratic endorsement pattern: newspapers with a higher propensity to endorse Democratic candidates give relatively more coverage to scandals involving Republican politicians than scandals involving Democratic politicians, while Republicanleaning newspapers do the opposite. This is robust across specifications, and is consistent with supply-driven models of media bias.

Regarding the partisanship of demand, there is no statistically significant relationship with the dependent variable. However, when controlling for endorsement partisanship the point estimate suggests that the Democratic partisanship of readers is negatively correlated with pro-Democratic coverage of scandals. ${ }^{24}$ Thus, the results do not lend support to demand-driven theories of media bias, which predict that slanted coverage should be in tune with the a priori views of consumers.

As discussed at the end of section 2.1, competitive pressure in the media market should compress the bias in coverage if the latter originates from the ideological position on the supply side. The same is true if newspapers face Bayesian consumers who are uncertain about the quality of news reporting, as in Gentzkow and Shapiro [2006]. On the other hand, competition would exacerbate bias if newspapers cater to confirmation-seeking readers.

To shed some empirical light on these contrasting predictions, we checked whether the

\footnotetext{
${ }^{24}$ This correlation is not far away from mild significance when controlling for total circulation.
} 
partial correlation of $\hat{s}_{j}$ with our measures of endorsement and reader partisanship is weaker or stronger in more competitive media environments. We consistently find a negative relationship - implying that more competition reduces supply-led bias - but the coefficients are rarely statistically significant (at the .05 level). ${ }^{25}$

\subsection{Overall coverage of scandals}

As discussed in section 2.1, if demand for information by consumers is what drives mass media behavior, then newspapers appealing to moderate voters should devote more total coverage to political scandals, irrespective of the political affiliation of the public officials involved. Also, there are reasonable conditions under which newspapers that are read by larger and ideologically more heterogeneous audiences would find it profitable to cover all scandals, in order to satisfy (to some extent) all customers.

In this section we again adopt a two stage approach, but the focus of the analysis is on overall coverage. Let $n_{i j}$ be the relative frequency of articles about scandal $i$ being published by newspaper $j$ during the relevant time period: differently from the previous section, we jointly look at Democratic and Republican scandals and run the following panel data regression:

$$
n_{i j}=\alpha_{i}+\beta_{j}+\delta_{1} \text { Instate }_{i j}+\delta_{2} \text { Local }_{i j}+\epsilon_{i j}
$$

where $\alpha_{i}$ and $\beta_{j}$ are scandal-specific and newspaper-specific fixed effects, respectively. As before, we control for the geographical proximity of each scandal. In the second stage, the estimated $\beta_{j}$ s are regressed against a set of newspaper-specific variables. Controlling for endorsement and reader partisanship, our focus is on the partial correlation with average yearly circulation (here expressed in thousand of copies) and $N R \_s d_{j}$.

The results are presented in Table 4, where we again distinguish between total hits, news articles, and editorials. For each category of news items, we first control for circulation only,

\footnotetext{
${ }^{25}$ As often occurs with interacted variables, our data exhibit a substantial amount of multicollinearity, making it difficult to disentangle the role played by competitive forces in determining slanted coverage.
} 
then add the voter standard deviation variable. ${ }^{26}$

The patterns are consistent. Overall coverage of scandals is significantly higher for newspapers with higher circulation. This is also true for news articles, but not for editorials. ${ }^{27}$

\section{One-Stage Analysis}

In this section we pool all of the data and perform a one-stage analysis with interaction terms. This is an alternative and more direct way to estimate whether the coverage of Democratic and Republican scandals of the various newspapers differs as a function of the endorsement score and the ideological leaning of readers. It also allows to delve further into the data, and investigate whether demand-driven or supply-led coverage bias is a function of specific features of the scandals themselves, such as their location.

Since we are exploiting the differential coverage of Republican and Democratic scandals by each newspaper, it is possible to include newspaper-specific fixed effects. More specifically, we run the following regression:

$$
n_{i j}=\alpha_{i}+\beta_{j}+\gamma\left(N E_{j} \times R S_{i}\right)+\delta_{1} \text { Instate }_{i j}+\delta_{2} \text { Local }_{i j}+\epsilon_{i j}
$$

where $R S_{i}$ is a dummy which equals one when scandal $i$ involves a Republican politician, and minus one when it involves a Democrat. We also run a regression in which we instead control for the interaction with the reader partisanship variable $N R_{j}$, and a third one where both interactions are included. In a fourth specification we check whether the slant in the coverage of scandals depends on the localness of the scandal itself. We do so by adding two triple interactions between $N E_{j}\left(N R_{j}\right), R S_{i}$ and a dummy which equals one if the politician involved in scandal $i$ is from the state where newspaper $j$ is located or from a congressional

\footnotetext{
${ }^{26}$ All of the specifications in Table 4 also include the endorsement and reader partisanship variables. We also ran specifications omitting those variables and the results are quite similar to those reported in the table.

${ }^{27}$ We also examine the effect of competition on total scandal coverage. We consistently find a negative relationship between competitiveness and overall coverage, but the estimated coefficients are seldom statistically significant (at the .05 level).
} 
district that overlaps heavily with the market area of newspaper $j .^{28}$

As in the previous section we separately consider total hits, news articles and editorials. Also, to account for the possibility that the error terms across observations are correlated within newspapers, we compute standard errors that are clustered by newspaper.

The results are shown in Table 5. The relative frequency of hits - for total hits, news hits, and editorial hits - is always positively and significantly correlated with the interaction between the endorsement score and the Republican scandal dummy. This corresponds to what we found in the two stage analysis. Moreover, the interaction between the partisanship of readers and the Republican dummy is negatively correlated with $n_{i j}$, although this coefficient is statistically insignificant. However, when allowing for a differential partisan behavior for local and non local scandals, we find that newspapers mainly read in Democratic (Republican) areas devote significantly more coverage only to those Republican (Democratic) scandals which involve local politicians. Interestingly, this demand-driven coverage bias does not occur on the editorial page, but only in the news section (and with total hits, as the latter effect dominates the former). On the other hand, supply-led coverage bias is not confined to local scandals, as shown by the positive and statistically significant coefficient on the simple interaction between $N E_{j}$ and $R S_{i}$. The triple interaction of $N E_{j}$ with the localness dummy is positive, but not significant.

A plausible interpretation of these results is that newspapers would pander to the ideological tastes of readers only by slanting news material which is already known to them. ${ }^{29}$ On the other hand, editors and journalists pursuing a partisan bias in their coverage appear to be making use of any news material that is suitable to the purpose, whether local or not.

The coefficient on the interaction term between $N E_{j}$ and $R S_{i}$ provides us with an estimate

\footnotetext{
${ }^{28}$ In other terms, this dummy equals one when the Instate or the Local dummies are equal to one, and zero otherwise.

${ }^{29}$ These results are also consistent with the existence of "favorable relationships" between newspapers and local politicians. On average, in a Democratic area the Democratic candidates may have well established relationships with the local people, including local newspapers owners and editors. These owners and editors might in turn show their friendship by suppressing coverage of scandals involving the local politicians. This is of course a supply side factor.
} 
of the differential coverage of Republican versus Democratic scandals by newspapers with different endorsement scores. Since the Republican scandal dummy takes on the values 1 and -1 , by multiplying the estimated coefficient by two and by the standard deviation of $N E_{j}$ (which equals 0.381 ), we obtain a measure of this differential coverage for newspapers that are one standard deviation apart on this endorsement dimension. In turn, we can divide this effect by the average fraction of hits, articles and editorials in our sample, in order to compute a relative measure of coverage bias. Doing this implies that a newspaper with an endorsement score which is one standard deviation more Democratic-leaning than another would dedicate 26 percent more coverage to Republican than to Democratic scandals. ${ }^{30}$ This effect is 30 percent for articles and 23 percent for editorials. A standard deviation in the endorsement score is what roughly separates the Chicago Tribune $\left(N E_{j}=-0.2498\right)$ from the Denver Post $\left(N E_{j}=0.1373\right)$, and in turn the Denver Post from the New York Times $\left(N E_{j}=0.4913\right)$.

In a parallel fashion, we can implement a one-stage analysis of the overall coverage of scandals. Since our focus in this case is on newspaper-specific variables such as total circulation and reader moderateness, we cannot use fixed effects at the newspaper level. Instead, we run the following regression:

$$
\begin{aligned}
n_{i j}=\alpha_{i}+\theta_{1} \operatorname{Circ}_{j}+\theta_{2} N R_{-} s d_{j}+ & \gamma\left(N E_{j} \times R S_{i}\right)+\phi\left(N R_{j} \times R S_{i}\right) \\
& +\delta_{1} \text { Instate }_{i j}+\delta_{2} \text { Local }_{i j}+\epsilon_{i j}
\end{aligned}
$$

Again, we estimate the partisan coverage of scandals by interacting the Republican scandal dummy with $N R_{j}$ and $N E_{j}$. Standard errors are again clustered at the newspaper level.

Table 6 displays the results. For each category of hits (total hits, articles and editorials) in the first specification we include only the circulation measure; we then add voter standard deviation. As in the two stage analysis, circulation is positively and significantly correlated with overall coverage in the case of total hits and news hits, but it is not significant for

\footnotetext{
${ }^{30}$ The calculation is $\frac{0.009 \times 2 \times 0.381}{0.0264} \approx 0.259$.
} 
editorials. On the other hand, voter standard deviation is positively and insignificantly correlated with coverage. The only exception is with editorials, where the relationship is positive and statistically significant. Finally, it is still the case that the interaction between endorsement partisanship and the Republican scandal dummy is positively and significantly correlated with coverage, while the interaction with reader partisanship is negatively and insignificantly correlated.

\subsection{Robustness checks}

In this section we explore the robustness of our findings, in particular of those regarding coverage bias. The scandals we analyze are characterised by some degree of heterogeneity. This is not altogether undesirable, since we are interested in a comprehensive investigation of coverage bias, and thus we care about the average behavior of newspapers across scandals of different types. On the other hand, one might be concerned that this average behavior is in fact a combination of largely different "treatments" newspapers devote to different types of scandals. Note, for example, that we have already found evidence that newspapers cater to partisan tastes of readers only when scandals involve local politicians.

The time periods of the various scandals is a first source of heterogeneity. In our case, all scandals except those involving Democratic politicians James Traficant (Rep-OH) and Edwin Edwards (Gov-LA) began after George W. Bush became president in 2000. A potential concern is that newspapers might be differentially covering political scandals as a function of the match between their political affiliation (as proxied by the endorsement score) and the overall partisan climate at the federal level, which is of course heavily influenced by the political affiliation of the incumbent president. If, for example, newspapers are more aggressive in the bias of their coverage of scandals when the president belongs to the least favorite political party, then the average differential coverage of scandals might change when the president changes. This would not affect our estimates of the relative partisan bias, but one cannot exclude the further possibility that Democratic-endorsing and Republican- 
endorsing outlets react to a change in the political affiliation of the president with a different degree of aggressiveness, hence confounding our results.

Again separately displaying results for total hits, news articles and opinion pieces, Table 7 presents the outcome of this robustness check in the first column of each subgroup, whereas we exclude the Traficant and Edwards scandals from the analysis. Throughout, we adopt the more general specification where we jointly control for endorsement and reader partisanship. The results are very close - in terms of magnitude and statistical significance - to those reported in Table 5.

Scandals might also differ on the basis of whether they have been formally investigated by a law-enforcement agency. In our sample there are three scandals which had not been formally investigated (at the time of this writing) - i.e., those involving Katherine Harris (Rep-R-FL), Dennis Hastert (Rep-R-IL) and Jim McGreevey (Gov-D-NJ). Similarly to the argument stated above, one might be worried that newspapers systematically differ in the amount of coverage they are willing to devote to scandals that are not formally investigated, as a function of the match between their political affiliation and that of the person involved. For example, newspapers could cover scandals that are not under formal investigation and that involve politicians on the opposite political side as vehemently as those which are formally investigated, while they could be even more parsimonious in the coverage of "informal" scandals, if they happen on their favorite political side. This would imply a more pronounced coverage bias on informal scandals.

The second column in each subgroup in Table 7 displays the results of dropping these cases. Again, the magnitude and statistical significance of the coefficients closely correspond to the ones obtained with the baseline sample.

Up to now we have attached the same weight to all scandals within each party, irrespective of the ideology of the politicians involved. However, it might be more rewarding for a Democratic-leaning (Republican-leaning) newspaper to cover scandals involving staunchly conservative Republicans (liberal Democrats) rather than moderate ones. This logic would 
also apply to demand-side forces driving newspapers to cater to confirmation-seeking readers. Poole and Rosenthal's (1997) NOMINATE scores provide a widely used measure of the ideological locations of all of the politicians who served in the U.S. Congress. ${ }^{31,32}$ For the 29 politicians to whom we can attach a NOMINATE common space score, we check whether the amount of coverage devoted by a Democratic-endorsing newspaper to a given scandal is increasing in the ideological conservativeness of the involved politician (as proxied by the NOMINATE score), and vice versa for a Republican-endorsing newspaper. In order to implement this type of analysis, we simply run a specification similar to (5), with the $R S_{i}$ dummy replaced by the NOMINATE common space score.

The last column for each subgroup of news items in Table 7 reports the findings of this last robustness check. The interaction between the endorsement score and the NOMINATE common space score has a positive and statistically significant coefficient (mildly so for news articles), while the interaction of the latter with the reader partisanship variable is negatively and insignificantly correlated with coverage, similarly to what found with the baseline specification.

\section{Discussion and Conclusions}

In this paper we have analysed the coverage of political scandals by a large number of U.S. newspapers, focusing on supply and demand side determinants of any partisan bias in this coverage. As more thoroughly discussed in section 2.2, the use of automated keyword-based searches of the online news archives (in our case: the NewsLibrary archive, plus Factiva and the newspaper's own archive for the New York Times, the Los Angeles Times and the

\footnotetext{
${ }^{31}$ The idea behind NOMINATE scores is to retrieve the ideological position of congressmen in a possibly multidimensional policy space on the basis of roll call votes cast (Poole and Rosenthal [1985], Poole and Rosenthal [1997]). Since we must compare politicians belonging to different chambers and at different points in time, we use the Common Space Scores (Poole [1998]), which are exactly designed to allow this type of comparison.

${ }^{32}$ In addition to the politicians who were members of the U.S. Congress at the time of the scandal in which they were involved, five of the governors served in the Congress before their election as governor and also have NOMINATE scores. They are Rod Blagojevich (D-IL), Edwin Edwards (D-LA), John Rowland (R-CT), Ernie Fletcher (R-KY) and Jim Gibbons (R-NV).
} 
Chicago Tribune) allows us to systematically investigate how U.S. newspapers covered all recent and salient political scandals, i.e. those involving senators, members of congress or state governors (plus Jack Abramoff).

The main finding is that the partisan leaning of the supply side has a strong correlation with the differential coverage of Democratic and Republican scandals: Democratic-leaning newspapers - i.e., those with a higher propensity to endorse Democratic candidates in elections - give significantly more coverage to scandals involving Republican politicians than scandals involving Democratic politicians, while Republican-leaning newspapers behave in the opposite way. This bias in the coverage of scandals is not confined to the editorial page, but also affects the news section. While the fraction of stories devoted to political scandals is on average very small, the magnitude of the coverage bias effect is very large in relative terms: the differential coverage of Republican versus Democratic scandals by a newspaper with a propensity to endorse Democratic candidates which is one standard deviation higher would be larger by around 26 percent.

On the other hand, we find that biased coverage of scandals "panders" to the partisan leaning of readers (as demand-driven models of mass media behavior by Mullainathan and Shleifer [2005] and Gentzkow and Shapiro [2006] would suggest) only for those scandals which are local - i.e. scandals involving politicians that are based in the same area where the newspaper is sold. From this point of view, while supply-led coverage bias would make use of any news material which is suitable to the purpose (i.e., any scandal on the opposite political side, irrespective of the geographical location of those involved), slanted coverage which caters to confirmation-seeking readers appears to be constrained by their ex ante preferences, in this case an interest for local people and events.

We also find some evidence regarding factors that are correlated with the overall coverage of scandals. Newspapers with higher circulation systematically devote more coverage to political scandals, at least in the news section. Further work is needed to distinguish between demand-driven and supply-led accounts for this relationship. 
Finally, regarding the issue of competition, we find no robust effects on bias or overall coverage. This may be in due in part to the fact that in the period we study most U.S. newspaper markets are relatively uncompetitive. Thus, it will be interesting to study earlier time periods, when the number of newspapers was larger and there was probably more variation in the degree of competition across cities. In addition, with historical data there are potential quasi-experiments we can exploit to better identify the effects of competition on media coverage. One is the demise of afternoon newspapers. Many scholars argue that this was caused by the spread of television and/or lifestyle changes, and therefore the decline can be treated as an exogenous shock to newspaper markets. If so, we can obtain a clean estimate of the effects of competition by comparing changes in newspaper coverage across cities with different initial numbers of afternoon newspapers.

\section{References}

[1] Anderson, S. P. and McLaren, J. [2005]. "Media Mergers and Media Bias with Rational Consumers" . Mimeo, University of Virginia.

[2] Ansolabehere, S., Lessem, R. and Snyder, J. M., Jr. [2006]. "The Orientation of Newspaper Endorsements in U.S. Elections, 1940-2002." Quarterly Journal of Political Science, 1(4): 393-404.

[3] Antweiler, W. and Frank, M. Z. [2005]. "Do US Stock Markets Typically Overreact to Corporate News Stories?" Mimeo, Sauder School of Business, University of British Columbia.

[4] Balkin, J. M. [1999]. "How Mass Media Simulate Political Transparency." Cultural Values, 3(4): 393-413.

[5] Bennett, W. L. and Serrin, W. [2005]. "The Watchdog Role." In G. Overholser and K. H. Jamieson (eds.), The Press. New York: Oxford University Press: 169-188. 
[6] Bernhardt, D., Krasa, S. and Polborn, M. K. [2006], "Political Polarization and the Electoral Effects of Media Bias." CESifo Working Paper Series No. 1798, available at SSRN: http://ssrn. com/abstract=892475.

[7] Bernstein, B. J. [1976]. "Road to Watergate and beyond: the growth and abuse of executive authority since 1940." Law and Contemporary Problems, 40: 58-86.

[8] Besley, T. and Prat, A. [2006]. "Handcuffs for the Grabbing Hand? Media Capture and Government Accountability." American Economic Review, 96(3): 720-736.

[9] Canes-Wrone, B., Herron, M. C. and Shotts, K. W. [2001]. "Leadership and Pandering: A Theory of Executive Policymaking." American Journal of Political Science, 45: 532550.

[10] Chomsky, N. [1973]. "Watergate: a skeptical view." New York Review of Books, September 20: 3-8.

[11] DellaVigna, S. and Kaplan, E. [2007]. "The Fox News Effect: Media Bias and Voting". Quarterly Journal of Economics, 122: 1187-1234.

[12] Francke, W. [1995]. "The Evolving Watchdog: The Media's Role in Government Ethics." Annals of the American Academy of Political and Social Science, 537: 109-121.

[13] Gasper, J. T. [2007]. "Ideological Shift: Explaining the Liberal Media Myth." Mimeo, Carnegie Mellon University. Available at http: //www . andrew. cmu . edu/user/gasper/WorkingPapers/Rep.pdf.

[14] Gentzkow, M. A., Glaeser, E. L. and Goldin, C. [2006]. "The Rise of the Fourth Estate: How Newspapers Became Informative and Why it Mattered." In E. L. Glaeser and C. Goldin (eds.), Corruption and Reform: Lessons from America's History. National Bureau of Economic Research. 
[15] Gentzkow, M. A. and Shapiro, J. M. [2006] "Media Bias and Reputation." Journal of Political Economy, 114(2): 280-316.

[16] Gentzkow, M. A. and Shapiro, J. M. [2007]. "What Drives News Media Slant? Evidence from U.S. Daily Newspapers." Mimeo, University of Chicago. Available at http: //faculty . chicagogsb.edu/matthew.gentzkow/biasmeas052507.pdf

[17] Gerber, A., Karlan, D. and Bergan, D. [2006]. "Does The Media Matter? A Field Experiment Measuring the Effect of Newspapers on Voting Behavior and Political Opinions." Mimeo, Yale University.

[18] Groseclose, T. and Milyo, J. [2005]. "A Measure of Media Bias" . Quarterly Journal of Economics, 120(4): 1191-1237.

[19] Iyengar, S., Kinder, D. R., and Peters, M. D. [1982]. "Experimental Demonstrations of the 'Not-So-Minimal' Consequences of Television News Programs." The American Political Science Review, 76(4): 848-858.

[20] Krosnick, J. A. and Miller, J. M. [1996]. "The Anatomy of News Media Priming." In S. Iyengar and R. Reeves (eds.), Do the Media Govern? Politicians, Voters, and Reporters in America. Thousand Oaks, Sage.

[21] Lang, G. E. and Lang, K. [1980]. "Polling on Watergate: the battle for public opinion." Public Opinion Quarterly, 44: 530-47.

[22] Larcinese, V. [2006]. "Information Acquisition, Ideology and Turnout: Theory and Evidence from Britain." Political Economy and Public Policy (PEPP) Working Paper n. 18, STICERD, London School of Economics.

[23] Larcinese, V., Puglisi R. and Snyder, J. M., Jr. [2007]. "Partisan Bias in Economic News: Evidence on the Agenda-Setting Behavior of U.S. Newspapers". NBER Working Paper No. W13378. 
[24] Lott, J. R., Jr. and Hassett, K. A. [2004]. "Is Newspaper Coverage of Economic Events Politically Biased?" Working Paper, American Enterprise Institute, Washington, DC. Available at http://ssrn. com/abstract $=588453$.

[25] Lippmann, W. [1922]. Public Opinion. New York, Harcourt, Brace.

[26] Lipset, S. M. and Rabb, E. [1973]. "An appointment with Watergate." Commentary, 56: $35-43$.

[27] McCombs, M. E. [2002]. "The Agenda-Setting Role of the Mass Media in the Shaping of Public Opinion." Paper presented at Mass Media Economics 2002 Conference, London School of Economics: http://sticerd.1se.ac.uk/dps/extra/McCombs.pdf

[28] McCombs, M. E. and Shaw, D. L. [1972]. "The Agenda-Setting Function of Mass Media". Public Opinion Quarterly, 36(2): 176-187.

[29] Mullainathan, S. and Shleifer, A. [2005]. "The Market for News". American Economic Review, 95(4): 1005-1030.

[30] Petrocik, J. R. [1996]. "Issue Ownership in Presidential Elections, with a 1980 Case Study." American Journal of Political Science, 40(3): 825-850.

[31] Petrova, M. [2007]. "Newspapers and Parties: How Advertising Revenues Created an Independent Press." Mimeo, Government Department, Harvard. Available at: http://www.gov.harvard.edu/student/mpetrova/Newspapers_Parties.pdf.

[32] Poole, K. T. [1998]. "Recovering a Basic Space From a Set of Issue Scales." American Journal of Political Science, 42: 954-993.

[33] Poole, K. T. and Rosenthal, H. [1985]. "A Spatial Model for Legislative Roll Call Analysis" American Journal of Political Science, 29(2): 357-384. 
[34] Poole, K. T. and Rosenthal, H. [1997]. Congress: A Political-Economic History of Roll Call Voting. New York: Oxford University Press.

[35] Puglisi, R. [2006]. "Being the New York Times: the Political Behaviour of a Newspaper." Political Economy and Public Policy (PEPP) Working Paper n. 20, STICERD, London School of Economics.

[36] Schrag, P. [1974]. "Watergate as entertainment." Social Policy, 5: 23-26.

[37] Szasz, A. [1986]. "The Process and Significance of Political Scandals: A Comparison of Watergate and the 'Sewergate' Episode at the Environmental Protection Agency." Social Problems, 33(3): 202-217.

[38] Wallis, J. J. [1984]. "The Birth of the Old Federalism: Financing the New Deal." Journal of Economic History, 47: 97-102.

[39] Wright, G. [1974]. "The Political Economy of New Deal Spending: An Econometric Analysis." Review of Economics and Statistics, 56: 30-38.

[40] Zimmer, T. A. [1979]. "Impact of Watergate on the public's trust in people and confidence in the mass media." Social Science Quarterly, 59: 743-51. 


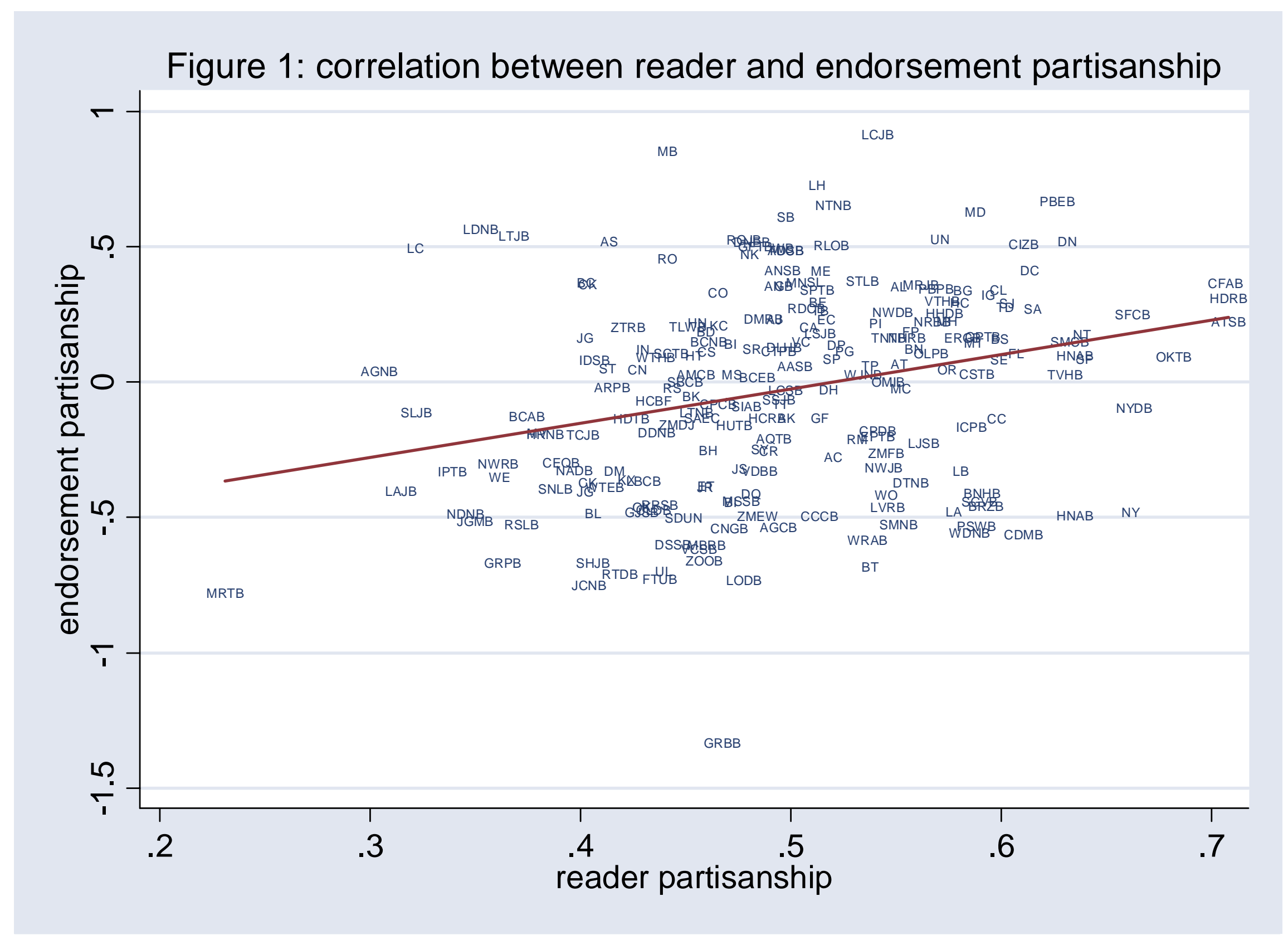


Table 1: Summary of covered political scandals

\begin{tabular}{|c|c|c|c|c|c|c|}
\hline Name & Position & State & Party & Scandal & Under Investigation & Time Window \\
\hline James Traficant & |House & Ohio & $\bar{D}$ & Bribery, false tax returns, racketeering, forcing aides to clean up his farm & & $1 / 1 / 1997$ to $9 / 30 / 2002$ \\
\hline Frank Ballance & House & North Carolina & $\mathrm{D}$ & Money Laundering and other charges from funds as a State Senator & Justice, December 2003 & $11 / 1 / 2003$ to $1 / 31 / 2006$ \\
\hline Robert Torricelli & Senate & New Jersey & D & Bribery related to Chinese connections, acceptance of campaign gifts & \begin{tabular}{|l|} 
Senate \\
2002
\end{tabular} & $4 / 1 / 2001$ to $11 / 30 / 2002$ \\
\hline William Jefferson & House & Louisiana & D & Bribery, fraud & $\mathrm{FBI}$, as of July, 2005 & $6 / 1 / 2005$ to $6 / 30 / 2007$ \\
\hline \begin{tabular}{|l|l} 
Jane Harman \\
\end{tabular} & House & California & $\mathrm{D}$ & Possible improper contact with AIPAC & FBI in 2005 & 10/1/2006 to $6 / 30 / 2007$ \\
\hline Paul Kanjorski & House & Pennsylvania & D & Funnelling of money into family business & $\mathrm{FBI}, 2002$ & $2 / 1 / 2002$ to $6 / 30 / 2007$ \\
\hline Robert Menendez & Senate & New Jersey & D & $\begin{array}{l}\text { Conflict of interest problems dealing with renting out property to a nonprofit, as well as an } \\
\text { associate pressuring a psychiatrist involving hiring someone and prison contracts }\end{array}$ & & $8 / 1 / 2006$ to $6 / 30 / 2007$ \\
\hline Alan Mollohan & House & West Virginia & D & Misrepresentation of private assets, earmarking funds to an aide & \begin{tabular}{|l|}
$\mathrm{FBI}$ (possibly preliminary) \\
2006; Justice Department
\end{tabular} & $2 / 1 / 2006$ to $6 / 30 / 2007$ \\
\hline Ed Mezvinsky & House & Iowa & $\mathrm{D}$ & Bank fraud, mail fraud, wire fraud & & $3 / 1 / 2001$ to $1 / 31 / 2003$ \\
\hline Jim McDermott & House & Washington & $\mathrm{D}$ & Eavesdropping on Gingrich/Boehner conversation & House Ethics & $12 / 1 / 2004$ to $12 / 31 / 2006$ \\
\hline Don Siegelman & Governor & Alabama & D & $\begin{array}{l}\begin{array}{l}\text { Racketeering and extortion dealing with HealthSouth and doctor's boards (as well as } \\
\text { trading favors for campaign contributions }\end{array} \\
\text { that }\end{array}$ & Since 05 & $10 / 1 / 2005$ to $6 / 30 / 2007$ \\
\hline Jim McGreevey & Governor & New Jersey & $\mathrm{D}$ & $\begin{array}{l}\text { Investigation of qualifications of staff, as well as pay to play and eventually revelations } \\
\text { about his relations with his national security advisor }\end{array}$ & & $8 / 1 / 2004$ to $12 / 31 / 2004$ \\
\hline Rod Blagojevich & Governor & Illinois & D & Kickback connections, hiring irregularities & | Justice $\begin{array}{c}\text { has open } \\
\text { investigation (July 2006) }\end{array}$ & 8/1/2005 to $6 / 30 / 2007$ \\
\hline Edwin Edwards & Governor & Louisiana & $\mathrm{D}$ & Racketeering, payoffs for casinos & 1998 (Justice) & $11 / 1 / 1998$ to $1 / 31 / 2001$ \\
\hline Randy "Duke" Cunningham & House & California & R & $\begin{array}{l}\text { Accepted } \$ 2.4 \text { million in bribes and underreported income from dealings with MZM inc., a } \\
\text { defense contractor. }\end{array}$ & giu-05 & $5 / 1 / 2005$ to $3 / 31 / 2006$ \\
\hline Bob Ney & House & Ohio & $\mathrm{R}$ & Abramoff-related & $\begin{array}{l}\text { May } 2006 \text { (House Ethics), } \\
\text { though investigation had }\end{array}$ & $10 / 1 / 2005$ to $4 / 1 / 2007$ \\
\hline Rick Renzi & House & Arizona & $R$ & $\begin{array}{l}\text { Bribery involving land swapping for copper mines, possible links to the US Attorneys probe, } \\
\text { also did not disclose } \$ 200 \mathrm{k} \text { from business associate }\end{array}$ & 2006-2007, Justice & $10 / 1 / 2006$ to $6 / 30 / 2007$ \\
\hline John Doolittle & House & California & $R$ & $\begin{array}{l}\text { Abramoff-related, dealing with money given to wife for undefined work and Doolittle's work } \\
\text { to get Indian casino for lowa tribe }\end{array}$ & $\begin{array}{l}\text { FBI investigation, raid Aprii } \\
13\end{array}$ & $12 / 1 / 2004$ to $6 / 30 / 2007$ \\
\hline Conrad Burns & Senate & Montana & $\mathrm{R}$ & Pay for play, Abramoff connections on getting money for Michigan Indian tribe & Justice, November 2005 & $3 / 1 / 2005$ to $11 / 31 / 2006$ \\
\hline Mark Foley & House & Florida & $R$ & Inappropriate emails to Congressional Pages & \begin{tabular}{|l}
$\mathrm{FBI}$ and House Ethics \\
Investigations
\end{tabular} & 9/1/2006 to $6 / 30 / 2007$ \\
\hline Tom DeLay & House & Texas & $\mathrm{R}$ & \begin{tabular}{|l|} 
Illegal corporate donations through TRMPAC as part of redistricting plan, money \\
laundering, aides and personal connections to Jack Abramoff investigation
\end{tabular} & mag-05 & $4 / 1 / 2005$ to $6 / 30 / 2007$ \\
\hline Bill Frist & Senate & Tennessee & $\mathrm{R}$ & Insider trading & SEC, 2006 & 9/1/2005 to $5 / 31 / 2007$ \\
\hline Jim Kolbe & House & Arizona & $\mathrm{R}$ & Page-related trips & $\begin{array}{l}\text { Preliminary investigation } \\
\text { October } 2006\end{array}$ & 9/1/2006 to $6 / 30 / 2007$ \\
\hline Curt Weldon & House & Pennsylvania & $R$ & Influence trading/bribery & FBI, October 2006 & $10 / 1 / 2006$ to $6 / 30 / 2007$ \\
\hline Jerry Lewis & House & California & $R$ & Bribery dealing with ties to former Rep. Bill Lowery & $\mathrm{FBI}$ & $12 / 1 / 2005$ to $6 / 30 / 2007$ \\
\hline Gary Miller & House & California & $\mathrm{R}$ & Failure to report land deals & $\mathrm{FBI}$ & $12 / 1 / 2006$ to $6 / 30 / 2007$ \\
\hline Katherine Harris & House & Florida & $\mathrm{R}$ & Duke Cunningham-MZM related & \begin{tabular}{|l|} 
Inquiries and interviews \\
about money received from
\end{tabular} & $6 / 1 / 2005$ to $11 / 31 / 2006$ \\
\hline Dennis Hastert & House & Illinois & $R$ & Bribery, Abramoff-related & \begin{tabular}{|l|}
$\begin{array}{l}\text { FBI (Reported May 2006, } \\
\text { though Justice have denied }\end{array}$ \\
\end{tabular} & $5 / 1 / 2006$ to $6 / 30 / 2007$ \\
\hline John Rowland & Governor & Connecticut & $\mathrm{R}$ & $\begin{array}{l}\text { Corruption and fraud stemming from work done on his weekend cottage, as well as } \\
\text { dealings on a home in Washington }\end{array}$ & $\begin{array}{l}2003 \text { (state and federal, with } \\
\text { state investigation }\end{array}$ & $11 / 1 / 2003$ to $3 / 31 / 2005$ \\
\hline George Ryan & Governor & Illinois & $R$ & $\begin{array}{l}\text { Racketeering and corruption, illegal sales of government licenses, bribery to give truck } \\
\text { drivers jobs, payments to family and others for no work. }\end{array}$ & & $1 / 1 / 2000$ to $9 / 30 / 2006$ \\
\hline Robert Taft & Governor & Ohio & $R$ & Failure to disclose gitts and trips given by lobbyists & 2005 & $6 / 1 / 2005$ to $8 / 31 / 2005$ \\
\hline Ernie Fletcher & Governor & Kentucky & $\mathrm{R}$ & Merit system related corruption (hiring and firing based on political loyalty) & $\begin{array}{l}\text { State Attorney General (May } \\
\text { 2005) }\end{array}$ & |5/1/2005 to $8 / 31 / 2006$ \\
\hline Jim Gibbons & House/Governor & Nevada & $R$ & Bribery (Gifts given for votes on Armed Services and Intelligence Committee) & $\begin{array}{l}\text { Justice } \\
\text { preliminary corruption }\end{array}$ & $11 / 1 / 2006$ to $6 / 30 / 2007$ \\
\hline Jack Abramoff & Lobbyist & & $\mathrm{R}$ & Defrauding of American Indian tribes and corruption of public officials & & $3 / 1 / 2004$ to $6 / 30 / 2007$ \\
\hline 1. Lewis "Scooter" Libby & \begin{tabular}{|l|l|}
$\begin{array}{l}\text { Chief of Staff, Vice } \\
\text { President }\end{array}$ & \\
\end{tabular} & & $\mathrm{R}$ & Perjury and involvement in the Valerie Plame CIA Leak Investigation & October 21, 2003 (Justice) & $10 / 1 / 2005$ to $3 / 31 / 2007$ \\
\hline
\end{tabular}


Table 2: summary statistics on scandals coverage

Variable

No of obs.

Mean Median Std. Dev.

Min

$\operatorname{Max}$

Scandal-newspaper level

relative frequency of scandal stories (total)

relative frequency of scandal articles

6881

6880

0.0264

0.0026

0.1023

0.0843

3.152

relative frequency of scandal editorials

6879

0.0203

0.0007

$\begin{array}{ll}0 & 0.4314 \\ 0 & 0.2026\end{array}$

6881

0.0429

Local

6881

0.0042

$0 \quad 0.0648$

\begin{tabular}{rrrrrr}
213 & -0.0232 & 0.0287 & 0.381 & -1.332 & 0.914 \\
213 & 0.5007 & 0.4974 & 0.0821 & 0.2309 & 0.708 \\
213 & 150353 & 82004 & 167877 & 7293 & 1088391 \\
213 & 0.0936 & 0.0909 & 0.0273 & 0.0311 & 0.1766 \\
207 & 0.1287 & 0.1202 & 0.0655 & 0.0124 & 0.25 \\
\hline
\end{tabular}

Newspaper level

NE (newspaper endorsement score)

NR (newspaper readership score)

total circulation

NR_sd (standard deviation of Democratic vote)

0.1287

0.1202

0.0655

0.0124

Notes: all relative frequencies of stories are expressed in percentage points. The Instate dummy equals one when the politician involved in a scandal is from the state where a newspaper is located. The Local dummy equals one when the politician involved in a scandal is from a congressional district that overlaps heavily with the market area of newspaper (for congressional scandals). 
Table 3: agenda bias in the coverage of political scandals, two-stage analysis

\begin{tabular}{|c|c|c|c|c|c|c|c|c|c|c|c|c|}
\hline & \multicolumn{4}{|c|}{ total hits } & \multicolumn{4}{|c|}{ articles } & \multicolumn{4}{|c|}{ editorials } \\
\hline & (1) & $(2)$ & (3) & $(4)$ & (5) & (6) & $(7)$ & $(8)$ & (9) & $(10)$ & $(11)$ & $(12)$ \\
\hline endorsement partisanship & $\begin{array}{c}0.015^{\star \star} \\
{[2.40]}\end{array}$ & - & $\begin{array}{c}0.017^{\star * *} \\
{[2.44]}\end{array}$ & $\begin{array}{c}0.0159^{\star *} \\
{[2.33]}\end{array}$ & $\begin{array}{c}0.013^{\star *} \\
{[2.50]}\end{array}$ & - & $\begin{array}{c}0.014^{\star *} \\
{[2.53]}\end{array}$ & $\begin{array}{c}0.0134^{\star \star} \\
{[2.40]}\end{array}$ & $\begin{array}{c}0.060 * * \\
{[2.52]}\end{array}$ & - & $\begin{array}{c}0.066^{\star \star *} \\
{[2.61]}\end{array}$ & $\begin{array}{c}0.0642^{\star *} \\
{[2.51]}\end{array}$ \\
\hline reader partisanship & - & $\begin{array}{l}0.005 \\
{[0.24]}\end{array}$ & $\begin{array}{l}-0.02 \\
{[0.90]}\end{array}$ & $\begin{array}{c}-0.0335 \\
{[1.58]}\end{array}$ & - & $\begin{array}{l}0.004 \\
{[0.23]}\end{array}$ & $\begin{array}{c}-0.017 \\
{[0.90]}\end{array}$ & $\begin{array}{c}-0.0295 \\
{[1.64]}\end{array}$ & - & $\begin{array}{l}0.012 \\
{[0.14]}\end{array}$ & $\begin{array}{l}-0.087 \\
{[0.99]}\end{array}$ & $\begin{array}{c}-0.1314 \\
{[1.49]}\end{array}$ \\
\hline total circulation (hundred of thousands & - & - & - & $\begin{array}{c}0.0030^{\star \star \star} \\
{[2.70]}\end{array}$ & - & - & - & $\begin{array}{c}0.0028^{\star \star \star} \\
{[2.94]}\end{array}$ & - & - & - & $\begin{array}{c}0.0097 \\
{[1.58]}\end{array}$ \\
\hline constant & $\begin{array}{c}0.010^{* \star *} \\
{[4.90]}\end{array}$ & $\begin{array}{l}0.007 \\
{[0.72]}\end{array}$ & $\begin{array}{l}0.020^{\star} \\
{[1.80]}\end{array}$ & $\begin{array}{c}0.0223^{\star *} \\
{[2.04]}\end{array}$ & $\begin{array}{c}0.008^{\star \star *} \\
{[4.88]}\end{array}$ & $\begin{array}{l}0.006 \\
{[0.71]}\end{array}$ & $\begin{array}{l}0.017^{\star} \\
{[1.76]}\end{array}$ & $\begin{array}{c}0.0190^{* *} \\
{[2.03]}\end{array}$ & $\begin{array}{c}0.049^{* * *} \\
{[5.53]}\end{array}$ & $\begin{array}{l}0.041 \\
{[0.95]}\end{array}$ & $\begin{array}{c}0.092^{\star *} \\
{[1.99]}\end{array}$ & $\begin{array}{c}0.0998^{\star *} \\
{[2.17]}\end{array}$ \\
\hline Observations & 213 & 213 & 213 & 213 & 213 & 213 & 213 & 213 & 213 & 213 & 213 & 213 \\
\hline R-squared & 0.04 & 0 & 0.04 & 0.07 & 0.04 & 0 & 0.04 & 0.07 & 0.03 & 0 & 0.03 & 0.05 \\
\hline
\end{tabular}

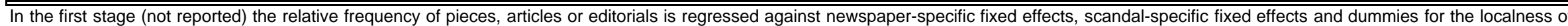

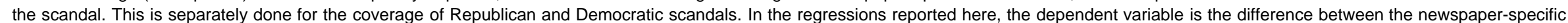

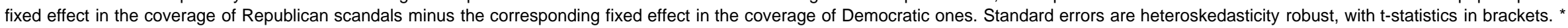
significant at $10 \%$; ** significant at $5 \%$; ** significant at $1 \%$. 
Table 4: overall coverage of political scandals, two-stage analysis

\begin{tabular}{|c|c|c|c|c|c|c|}
\hline & \multicolumn{2}{|c|}{ total hits } & \multicolumn{2}{|c|}{ articles } & \multicolumn{2}{|c|}{ editorials } \\
\hline & $(1)$ & $(2)$ & $(3)$ & $(4)$ & $(5)$ & $(6)$ \\
\hline \multirow[t]{2}{*}{ total circulation (hundreds of thousands) } & $0.003^{* * *}$ & $0.003^{\star * *}$ & $0.003^{\star * *}$ & $0.003^{* * *}$ & 0.007 & $0.008 *$ \\
\hline & [3.67] & [3.68] & [4.27] & [4.30] & [1.65] & {$[1.71]$} \\
\hline \multirow[t]{2}{*}{ standard deviation of Democratic vote } & - & 0.012 & - & 0.019 & - & 0.206 \\
\hline & & [0.31] & & [0.53] & & [1.14] \\
\hline \multirow[t]{2}{*}{ endorsement partisanship } & 0.006 & 0.006 & 0.005 & 0.005 & 0.025 & 0.024 \\
\hline & [1.38] & [1.37] & [1.42] & [1.39] & [1.37] & [1.30] \\
\hline \multirow[t]{2}{*}{ reader partisanship } & -0.021 & -0.02 & -0.017 & -0.017 & -0.092 & -0.083 \\
\hline & [1.34] & [1.31] & [1.22] & [1.16] & [1.49] & [1.34] \\
\hline \multirow[t]{2}{*}{ constant } & $0.014^{*}$ & 0.013 & 0.011 & 0.009 & $0.075^{\star \star}$ & 0.052 \\
\hline & [1.76] & [1.39] & [1.47] & [1.00] & [2.34] & [1.29] \\
\hline Observations & 213 & 213 & 213 & 213 & 213 & 213 \\
\hline R-squared & 0.06 & 0.06 & 0.07 & 0.07 & 0.03 & 0.03 \\
\hline
\end{tabular}

In the first stage (not reported) the relative frequency of pieces, articles or editorials is regressed against newspaper-specific fixed effects, scandal-specific fixed effects and dummies for the localness of the scandal. This is jointly done for the coverage of Republican and Democratic scandals. In the regressions reported here, the dependent variable is the newspaper-specific fixed effect as estimated in the first stage. Standard errors are heteroskedasticity robust, with t-statistics in brackets. * significant at $10 \%$; ** significant at $5 \%$; *** significant at $1 \%$. 
Table 5: agenda bias in the coverage of political scandals, one-stage analysis

\begin{tabular}{|c|c|c|c|c|c|c|c|c|c|c|c|c|}
\hline & \multicolumn{4}{|c|}{ total hits } & \multicolumn{4}{|c|}{ articles } & \multicolumn{4}{|c|}{ editorials } \\
\hline & (1) & (2) & (3) & (4) & (5) & (6) & (7) & (8) & (9) & (10) & (11) & (12) \\
\hline endorsement score * Republican scandal dummy & $\begin{array}{c}0.009^{\star \star} \\
{[2.40]}\end{array}$ & - & $\begin{array}{c}0.009 * \star \\
{[2.42]}\end{array}$ & $\begin{array}{c}0.005^{\star \star *} \\
{[2.95]}\end{array}$ & $\begin{array}{c}0.007^{\star *} \\
{[2.48]}\end{array}$ & - & $\begin{array}{c}0.008^{\star \star} \\
{[2.50]}\end{array}$ & $\begin{array}{c}0.005^{\star \star \star} \\
{[2.77]}\end{array}$ & $\begin{array}{c}0.033^{\star * *} \\
{[2.69]}\end{array}$ & - & $\begin{array}{c}0.036^{\star \star *} \\
{[2.77]}\end{array}$ & $\begin{array}{c}0.024^{\star * \star} \\
{[3.03]}\end{array}$ \\
\hline $\begin{array}{l}\text { endorsement score * Republican scandal dummy * } \\
\text { dummy for local scandals }\end{array}$ & - & - & - & $\begin{array}{l}0.118 \\
{[1.32]}\end{array}$ & - & - & - & $\begin{array}{l}0.099 \\
{[1.33]}\end{array}$ & - & - & - & $\begin{array}{l}0.399 \\
{[1.47]}\end{array}$ \\
\hline reader partisanship * Republican scandal dummy & - & $\begin{array}{l}0.004 \\
{[0.34]}\end{array}$ & $\begin{array}{l}-0.01 \\
{[0.82]}\end{array}$ & $\begin{array}{l}-0.021 \\
{[1.55]}\end{array}$ & - & $\begin{array}{l}0.003 \\
{[0.34]}\end{array}$ & $\begin{array}{l}-0.008 \\
{[0.80]}\end{array}$ & $\begin{array}{l}-0.018 \\
{[1.58]}\end{array}$ & - & $\begin{array}{l}0.013 \\
{[0.31]}\end{array}$ & $\begin{array}{l}-0.041 \\
{[0.92]}\end{array}$ & $\begin{array}{l}-0.066 \\
{[1.37]}\end{array}$ \\
\hline $\begin{array}{l}\text { reader partisanship * Republican scandal dummy * } \\
\text { dummy for local scandals }\end{array}$ & - & - & - & $\begin{array}{c}0.094^{\star *} \\
{[2.35]}\end{array}$ & - & - & - & $\begin{array}{c}0.087^{\star \star \star} \\
{[2.65]}\end{array}$ & - & - & - & $\begin{array}{c}0.16 \\
{[0.97]}\end{array}$ \\
\hline same state for involved politician and newspaper & $\begin{array}{c}0.193^{\star \star \star} \\
{[6.80]}\end{array}$ & $\begin{array}{c}0.193^{\star \star \star} \\
{[6.80]}\end{array}$ & $\begin{array}{c}0.193^{\star \star \star} \\
{[6.80]}\end{array}$ & $\begin{array}{c}0.181^{\star \star *} \\
{[6.69]}\end{array}$ & $\begin{array}{c}0.155^{\star \star \star} \\
{[6.65]}\end{array}$ & $\begin{array}{c}0.155^{\star \star \star} \\
{[6.64]}\end{array}$ & $\begin{array}{c}0.155^{\star \star \star} \\
{[6.65]}\end{array}$ & $\begin{array}{c}0.144^{\star \star \star} \\
{[6.64]}\end{array}$ & $\begin{array}{l}0.779^{\star \star \star} \\
{[6.73]}\end{array}$ & $\begin{array}{l}0.778^{\star \star *} \\
{[6.72]}\end{array}$ & $\begin{array}{l}0.779^{\star \star \star *} \\
{[6.73]}\end{array}$ & $\begin{array}{c}0.768^{\star \star \star} \\
{[6.15]}\end{array}$ \\
\hline $\begin{array}{l}\text { same congressional district for involved politician and } \\
\text { newspaper }\end{array}$ & $\begin{array}{l}0.143^{* *} \\
{[2.42]}\end{array}$ & $\begin{array}{c}0.144^{\star *} \\
{[2.43]}\end{array}$ & $\begin{array}{c}0.143^{* *} \\
{[2.41]}\end{array}$ & $\begin{array}{c}0.138^{\star *} \\
{[2.41]}\end{array}$ & $\begin{array}{c}0.114^{\star \star} \\
{[2.32]}\end{array}$ & $\begin{array}{c}0.115^{\star *} \\
{[2.34]}\end{array}$ & $\begin{array}{c}0.114^{\star *} \\
{[2.32]}\end{array}$ & $\begin{array}{c}0.110^{\star *} \\
{[2.32]}\end{array}$ & $\begin{array}{l}0.629^{\star *} \\
{[2.55]}\end{array}$ & $\begin{array}{l}0.631^{* *} \\
{[2.56]}\end{array}$ & $\begin{array}{l}0.627^{\star *} \\
{[2.54]}\end{array}$ & $\begin{array}{c}0.600^{\star *} \\
{[2.50]}\end{array}$ \\
\hline constant & $\begin{array}{c}0.101^{\star \star \star} \\
{[4.68]}\end{array}$ & $\begin{array}{c}0.050^{\star \star \star} \\
{[8.50]} \\
\end{array}$ & $\begin{array}{c}0.043^{\star \star \star} \\
{[6.43]} \\
\end{array}$ & $\begin{array}{c}0.036^{\star \star \star} \\
{[4.73]} \\
\end{array}$ & $\begin{array}{c}0.042^{\star \star \star} \\
{[29.67]} \\
\end{array}$ & $\begin{array}{c}0.044^{\star \star \star} \\
{[8.66]} \\
\end{array}$ & $\begin{array}{c}0.038^{\star \star \star} \\
{[6.60]} \\
\end{array}$ & $\begin{array}{c}0.032^{\star \star \star} \\
{[4.86]} \\
\end{array}$ & $\begin{array}{c}0.351^{\star \star \star} \\
{[4.52]} \\
\end{array}$ & $\begin{array}{c}0.344^{\star \star \star} \\
{[4.13]} \\
\end{array}$ & $\begin{array}{c}0.372^{\star \star \star} \\
{[4.50]} \\
\end{array}$ & $\begin{array}{c}0.381^{\star \star \star} \\
{[4.53]} \\
\end{array}$ \\
\hline $\begin{array}{l}\text { newspaper fixed effects } \\
\text { scandal fixed effects }\end{array}$ & $\begin{array}{l}\text { yes } \\
\text { yes }\end{array}$ & $\begin{array}{l}\text { yes } \\
\text { yes }\end{array}$ & $\begin{array}{l}\text { yes } \\
\text { yes }\end{array}$ & yes & yes & yes & yes & yes & yes & yes & yes & yes \\
\hline Observations & 6881 & 6881 & 6881 & 6881 & 6880 & 6880 & 6880 & 6880 & 6879 & 6879 & 6879 & 6879 \\
\hline Number of newspapers & 213 & 213 & 213 & 213 & 213 & 213 & 213 & 213 & 213 & 213 & 213 & 213 \\
\hline R-squared & 0.3 & 0.3 & 0.3 & 0.31 & 0.27 & 0.27 & 0.27 & 0.29 & 0.34 & 0.34 & 0.34 & 0.35 \\
\hline
\end{tabular}

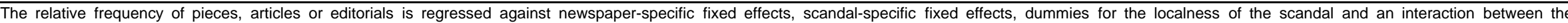

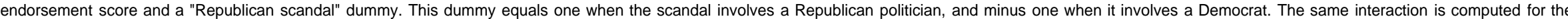

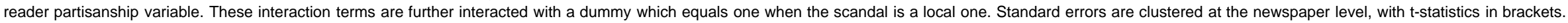

* significant at $10 \%$; ** significant at $5 \%$; *** significant at $1 \%$. 
Table 6: overall coverage of political scandals, one-stage analysis

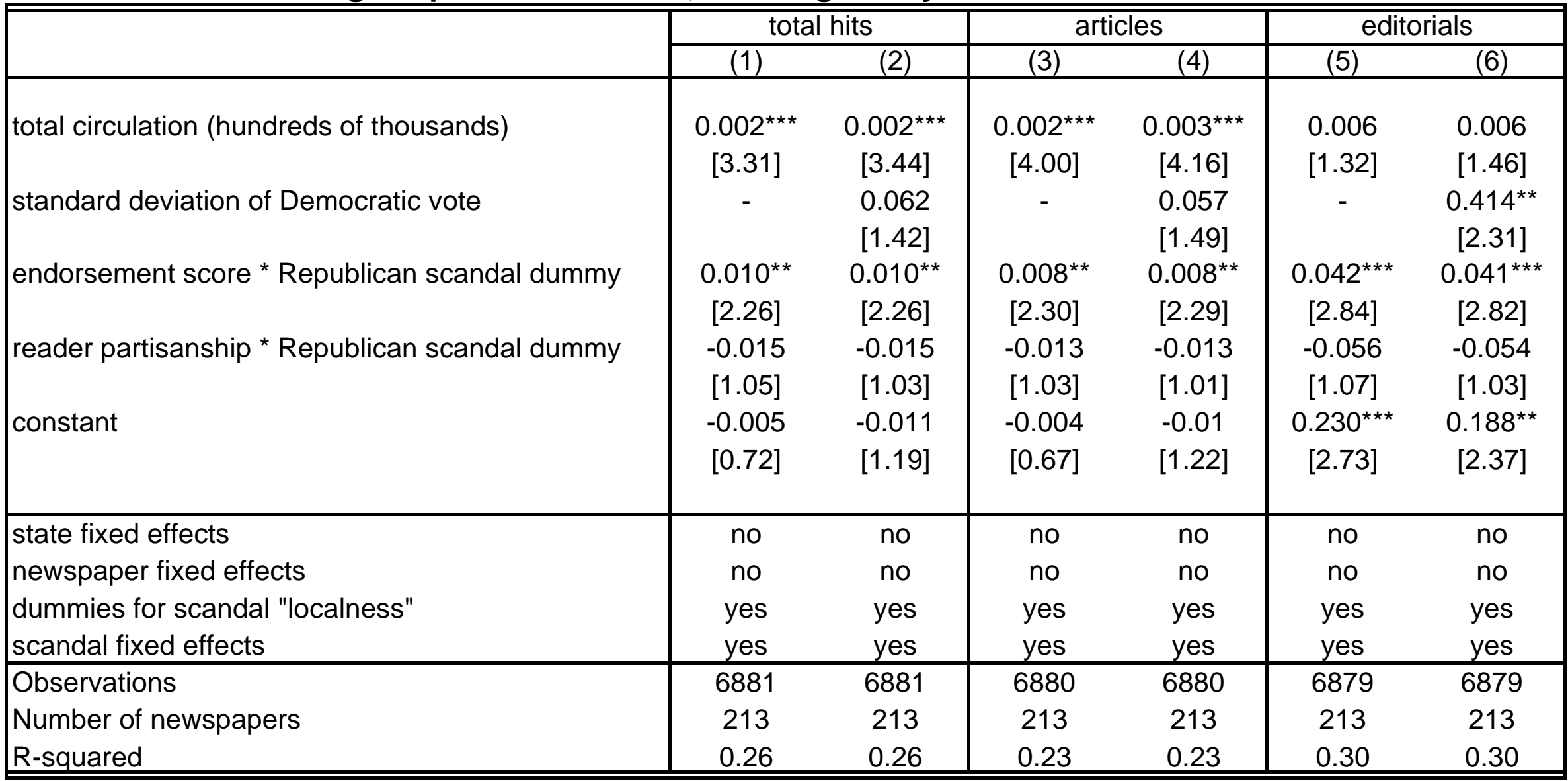

The relative frequency of pieces, articles or editorials is regressed against scandal-specific fixed effects, dummies for the localness of the scandal and an interaction between the endorsement score and a "Republican scandal" dummy. This dummy equals one when the scandal involves a Republican politician, and minus one when it involves a Democrat. The same interaction is computed for the reader partisanship variable. The focus is on total circulation of each newspaper and the standard deviation of the Democratic vote in the area where the newspaper is sold. Standard errors are clustered at the newspaper level, with t-statistics in brackets. * significant at $10 \%$; ** significant at $5 \%$; *** significant at $1 \%$. 
Table 7: robustness checks on agenda bias, one-stage analysis

\begin{tabular}{|c|c|c|c|c|c|c|c|c|c|}
\hline & \multicolumn{3}{|c|}{ total hits } & \multicolumn{3}{|c|}{ articles } & \multicolumn{3}{|c|}{ editorials } \\
\hline & recent scandals & $\begin{array}{c}\text { formally } \\
\text { investigated } \\
\text { scandals } \\
\end{array}$ & $\begin{array}{l}\text { interaction with } \\
\text { Nominate score }\end{array}$ & recent scandals & $\begin{array}{c}\text { formally } \\
\text { investigated } \\
\text { scandals } \\
\end{array}$ & $\begin{array}{l}\text { interaction with } \\
\text { Nominate score }\end{array}$ & recent scandals & $\begin{array}{c}\text { formally } \\
\text { investigated } \\
\text { scandals } \\
\end{array}$ & $\begin{array}{l}\text { interaction with } \\
\text { Nominate score }\end{array}$ \\
\hline endorsement score * Republican scandal variable & $0.010^{* *}$ & 0.009 ** & $0.023^{\star *}$ & $0.008^{\star *}$ & $0.008^{* *}$ & $0.018^{*}$ & $0.039 * * \star$ & $0.039 * \star \star$ & $0.100^{\star *}$ \\
\hline \multirow[t]{2}{*}{ reader partisanship * Republican scandal variable } & -0.009 & -0.006 & -0.003 & -0.008 & -0.004 & 0 & -0.041 & -0.033 & -0.103 \\
\hline & {$[0.74]$} & {$[0.50]$} & {$[0.07]$} & {$[0.72]$} & [0.43] & {$[0.01]$} & [0.91] & [0.73] & {$[0.77]$} \\
\hline same state for involved politician and newspaper & $\begin{array}{c}0.198 * * * \\
{[6.63]}\end{array}$ & $\begin{array}{c}0.203^{\text {*** }} \\
{[6.45]}\end{array}$ & $\begin{array}{c}0.142^{* * *} \\
{[5.72]}\end{array}$ & $\begin{array}{c}0.159 * * * \\
{[6.48]}\end{array}$ & $\begin{array}{c}0.164^{* * *} \\
{[6.35]}\end{array}$ & $\begin{array}{c}0.113^{* * *} \\
{[5.61]}\end{array}$ & $\begin{array}{c}0.796^{* * *} \\
{[6.59]}\end{array}$ & $\begin{array}{c}0.805^{\star \star \star *} \\
{[6.36]}\end{array}$ & $\begin{array}{c}0.572^{* * *} \\
{[5.98]}\end{array}$ \\
\hline \multirow{2}{*}{$\begin{array}{l}\text { same congressional district for involved politician and } \\
\text { newspaper } \\
\text { constant }\end{array}$} & $\begin{array}{c}0.150 * * \\
{[2.48]}\end{array}$ & $\begin{array}{c}0.129 * \star \\
{[1.98]}\end{array}$ & $\begin{array}{c}0.181 * \star \star \\
{[3.07]}\end{array}$ & $\begin{array}{c}0.119^{* *} \\
{[2.38]}\end{array}$ & $\begin{array}{c}0.105^{\star} \\
{[1.96]}\end{array}$ & $\begin{array}{c}0.145^{\star \star \star} \\
{[2.98]}\end{array}$ & $\begin{array}{c}0.641^{* *} \\
{[2.55]}\end{array}$ & $\begin{array}{c}0.528 * * \\
{[2.05]}\end{array}$ & $\begin{array}{c}0.787^{\star * \star} \\
{[3.19]}\end{array}$ \\
\hline & $\begin{array}{c}0.057^{\star \star \star} \\
{[8.74]}\end{array}$ & $\begin{array}{c}0.106^{\star \star \star} \\
{[4.51]}\end{array}$ & $\begin{array}{c}0.064^{\star \star \star} \\
{[12.57]}\end{array}$ & 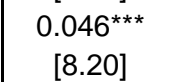 & $\begin{array}{c}0.089 * \star \star \\
{[4.44]}\end{array}$ & $\begin{array}{c}0.052^{\star \star \star} \\
{[12.21]}\end{array}$ & $\begin{array}{c}0.379 \star \star \star \\
{[4.66]}\end{array}$ & $\begin{array}{c}0.370^{\star \star \star \star} \\
{[4.49]}\end{array}$ & $\begin{array}{c}0.254^{\star \star \star} \\
{[8.60]}\end{array}$ \\
\hline \multirow{2}{*}{$\begin{array}{l}\text { newspaper fixed effects } \\
\text { scandal fixed effects }\end{array}$} & yes & yes & yes & yes & yes & yes & yes & yes & yes \\
\hline & yes & yes & yes & yes & yes & yes & yes & yes & yes \\
\hline Observations & 6542 & 6298 & 5694 & 6541 & 6297 & 5694 & 6540 & 6296 & 5694 \\
\hline Number of newspapers & 213 & 213 & 213 & 213 & 213 & 213 & 213 & 213 & 213 \\
\hline Number of scandals & 33 & 32 & 29 & 33 & 32 & 29 & 33 & 32 & 29 \\
\hline R-squared & 0.3 & 0.29 & 0.32 & 0.28 & 0.27 & 0.29 & 0.34 & 0.34 & 0.37 \\
\hline
\end{tabular}

The relative frequency of pieces, articles or editorials is regressed against newspaper-specific fixed effects, scandal-specific fixed effects, dummies for the localness of the scandal and an interaction between the endorsement score and a "Republican scandal" dummy. This dummy equals one when the scandal involves a Republican politician, and minus one when it involves a Democrat. The same interaction is computed for the reader partisanship variable. In the first column within each subgroup we restrict attention to recent scandals; in the second one we focus on formally investigated scandals, while in the last one we interact the endorsement score (and the reader partisanship variable) with the NOMINATE common space score of the person involved, if available. Standard errors are clustered at the newspaper level, with t-statistics in brackets. * significant at $10 \%$; ** significant at $5 \%$; *** significant at $1 \%$. 